\title{
In vitro Effect of Rhizobacterial Strains against Rice Root Knot Nematode Meloidogyne graminicola
}

\author{
Matcha Udaya Kumar*, R.K. Walia and R.S. Kanwar \\ Department of Nematology, CCS Haryana Agricultural University, \\ Hisar, Haryana-125 004, India \\ *Corresponding author
}

\begin{tabular}{l} 
Ke y w or d s \\
$\begin{array}{l}\text { Rhizobacterial strains, } \\
\text { Meloidogyne } \\
\text { graminicola, In vitro }\end{array}$ \\
\hline Article Info \\
$\begin{array}{l}\text { Accepted: } \\
\text { 20 November } 2018 \\
\text { Available Online: } \\
\text { 10 December } 2018\end{array}$ \\
\hline
\end{tabular}

A B S T R A C T
Five rhizospheric bacterial cultures and cell free culture filtrates (CFs) (one strain of Gluconacetobacter diazotrophicus (35-47), two strains of Azotobacter chroococcum viz. AVK-51, HT-54: two strains of Bacillus spp. viz., RKB-91, RKB-65) were evaluated for larval mortality and egg hatching against rice root-knot nematodes (Meloidogyne gramincola) at CCS HAU Hisar. The obtained data revealed that, among five bacterial isolates the bacillus strain of RKB-91 $(84.67 \%$ \& $81.00 \%)$ were the most effective bacteria at $\mathrm{S} / 2$ concentration in both cultures and CFs respectively at $48 \mathrm{hr}$, followed by Bacillus Sp. RKB-65. The lowest mortality $(05.00 \%)$ was observed in water mixture (control). whereas, these bacteria achieved the highest mortality percentages by more than $80 \%$. Results also indicated that among all bacterial strains Bacillus Sp. RKB-91 showed most inhibitory effect (28.0 and 31.00) of egg hatching at $\mathrm{S} / 2$ concentration followed by bacillus Sp. RKB-65 (36.33 and 41.00) and Azatobacter Spp. in both cultures and cell free culture filtrates after 10 days respectively.. The maximum egg hatching was recorded in water $(95 \%)$. It is revealed that all three factors viz, cultures, cell free culture filtrates and their concentrations significantly affected mortality and hatching individually.

\section{Introduction}

Plant parasitic nematodes cause significant damage and yield loss in rice (Oryza sativa L.), which is the staple food for more than three billion people of the world's population. More than 35 genera and 130 species of plant parasitic nematodes are associated with rice (Gerber et al., 1987). Among them, root-knot nematode, Meloidogyne graminicola Golden and Birchfield, a sedentary endoparasite of rice roots, is the major species affecting rice production (Soriano et al., 2000). Yield losses of between 20\% and 80\% (Padgham et al., 2004a; Soriano and Reversat, 2003). It impair the plant growth by inhibiting new root development, suppressing the rate of root extension, degeneration of existing roots and causing characteristic galls and the infected plants become yellow and stunted (Roy 1976). The rice root-knot nematode, Meloidogyne graminicola Golden \& Birchfield, is a severe pest of rice (Oryza sativa L.) in several rice producing areas and particularly in nursery 
beds, where flooding is intermittent or absent. Recently, severe infestations of $M$. graminicola were identified in several rice nursery seedbeds in Bangladesh, using a soil bioassay test (Padgham, 2003; Padgham et al., 2004a). Also, Padgham et al., (2004b) reported significant increases in seedling height and shoot dry weight of rice grown in seedbeds treated with carbofuran. The use of rice seedlings from non-treated nursery beds has resulted in yield loss of rice grain of 38\% in comparison to $29 \%$ when rice seedlings from treated nursery beds were used (Gaur, 2003), thus suggesting the importance of controlling nematodes in nursery beds. Use of chemical nematicide is commonly adopted methods for managing the $M$. graminicola in rice. Several studies supported the effectiveness of carbofuran to control $M$. graminicola in rice (Prasad and Rao 1985). However, since a decade ago, nematode management strategies have moved towards partial or complete avoidance of chemicals due to groundwater contamination and other environmental hazards. The lack of nematoderesistant rice cultivars, and the economic unavaibility of nematicide application, severely limits options for effective nematode management. Alternative strategies therefore need to be developed so that rice producers do not have to simply cope with the inevitable crop loss caused by this parasite. One such strategy would be to deploy a Rhizobacteria, Arable soils are a hub of microbial activity. Bacteria are numerically the most abundant organisms in the field soil but their biomass is somewhat less than that of the fungi although it exceeds that of the algae, protozoa and nematodes combined. Each cubic meter of an average fertile field may harbor up to $300 \mathrm{~g}$ bacteria, $400 \mathrm{~g}$ fungi, $39 \mathrm{~g}$ protozoa, and $12 \mathrm{~g}$ nematodes, besides other macro-organism comprising soil insects and other arthropods. It is, therefore, implied that biotic interactions among this ecologically complex ecosystem are very complicated. With plant parasitic nematodes at the center stage, it is worthwhile to imagine that the metabolic products released in the rhizosphere by this multiplicity of microorganisms are bound to influence nematodes directly or indirectly. It is also implicit that the antagonists of plant parasitic nematodes also exist in such ecological niches.

An overview of such complex interactions between plant parasitic nematodes and rhizospheric bacteria has been reviewed by some workers (Tian et al., 2007). These are considered ideal candidates for nematode control because of their antibiosis effects, due to the nematotoxic metabolites produced during their growth (Bansal and Bajaj, 2003) and also due to their high rate of multiplication, spread and colonization of the rhizosphere and plant root surface (Dobbelaere et al., 2003). In the light of the above information, an investigation was undertaken to evaluate the biocontrol potential of one strains of Gluconacetobacter diazotrophicus Yamada, Hoshino \& Ishikawa, two strains of Azotobacter chroococcum Beijerinek, and two of Bacillus spp., in vitro against $M$. graminicola infecting rice seedlings in laboratory conditions.

\section{Materials and Methods}

\section{Isolation of bacteria}

The bacteria used in this study were isolated from Nematode-infested soil. Five $g$ soil sample collected from nematode cultures pots was mixed in $45 \mathrm{ml}$ sterile distilled water $\left(10^{-}\right.$ ${ }^{1}$ dilution). One $\mathrm{ml}$ of this dilution was mixed in $9 \mathrm{ml}$ water blank to make $10^{-2}$ dilution and with similar procedure up to $10^{-7}$ dilutions were prepared. A $100 \mu$ sample of each dilution was spread on nutrient agar (NA) plate and incubated at $28^{\circ} \mathrm{C}$ for $48-72 \mathrm{~h}$. The colonies obtained on NA plates were picked and streaked on more NA plates and purified 
by re-streaking. The isolates were maintained on NA slants and stored at $4^{\circ} \mathrm{C}$. with the help of Department of Microbiology, CCS HAU, Hisar. Total five strains were identified which were used in this study i.e., one strain of Gluconacetobacter diazotrophicus (35-47), two strains of Azotobacter chroococcum viz. AVK-51, HT-54: two strains of Bacillus spp. viz., RKB-91, RKB-65 used in present study. Twenty $\mathrm{ml}$ of the culture broth was centrifuged at 10,000 rpm for 10 min to obtain cell-free culture filtrate $(\mathrm{CF})$. All bacterial cultures and culture filtrates were maintained for in-vitro experiments.

\section{Obtaining eggs and $\mathrm{J} 2$ of $M$. graminicola}

M. graminicola populations were obtained from rice roots grown in culture pots. Eggs of $M$. graminicola were extracted from infected rice roots either by teasing galled roots with needles or by using a modification of the Hussey-Barker method (Hussey and Barker 1973) wherein galled root pieces were placed in 0.1 per cent $\mathrm{NaOCl}$ solution and processed in a waring blender at $20 \mathrm{sec}$ intervals for 3 min. The water suspension bearing the free eggs was passed through a bank of sieves 100 mesh (pore size $150 \mu \mathrm{m}$ ) nested over 400 mesh $(38 \mu \mathrm{m})$ and 500 mesh $(26 \mu \mathrm{m})$ sieves. The contents of the sieves were washed thoroughly with running water to remove the chlorine. Finally the residues of 400 and 500 mesh sieves were collected in a beaker. The contents of the beaker were examined under a stereozoom microscope for the presence and density of eggs. The J2 were obtained by further pouring egg suspension over 4-ply facial tissue paper mounted on a piece of moulded wire net. The assembly was fixed in a Petri-plate and fresh water was added. The water was removed from the Petri-plate daily to collect the hatched $\mathrm{J} 2$ and replaced with fresh water. The assembly was maintained at $24 \pm 1^{\circ} \mathrm{C}$ in a BOD incubator until the $\mathrm{J} 2$ hatched. Freshly hatched J2 were used for the experiments according to the treatments.

\section{Tests for nematoxicity}

One $\mathrm{ml}$ of $\mathrm{S}, \mathrm{S} / 2, \mathrm{~S} / 4$ and $\mathrm{S} / 8$ dilutions of each culture and its cell-free culture (CFs) was mixed with $1 \mathrm{ml}$ nematode suspension (containing ca. 100 Meloidogyne graminicola $\mathrm{J} 2$ ) in 24-well sterile tissue-culture plates to obtain $\mathrm{S} / 2, \mathrm{~S} / 4, \mathrm{~S} / 8$ and $\mathrm{S} / 16$ dilutions of all the cultures and their CFs and tested for per cent mortality of nematodes. Observations on nematode mortality were recorded after $48 \mathrm{~h}$. The immobile $\mathrm{J} 2$ were confirmed for mortality by randomly disturbing with a needle. Sterile water alone served as control.

\section{Tests for hatching}

One $\mathrm{ml}$ of $\mathrm{S}, \mathrm{S} / 2, \mathrm{~S} / 4$ and $\mathrm{S} / 8$ dilutions of each culture and its cell-free $\mathrm{CF}$ was mixed with $1 \mathrm{ml}$ nematode suspension (containing ca. 100 eggs of Meloidogyne gramnicola) in 24-well sterile tissue-culture plates to obtain $\mathrm{S} / 2, \mathrm{~S} / 4, \mathrm{~S} / 8$ and $\mathrm{S} / 16$ dilutions of all the cultures and their CFs and tested for per cent hatching of nematodes. Observations on inhibition of egg hatching were recorded after 10 days. Sterile water served as control.

\section{Results and Discussion}

\section{Mortality test by cell cultures}

It is evident from (Table 1) that the rhizobacterial cultures caused larval mortality of $M$. graminicola. All the rhizobacterial strains resulted in nematode mortality ranging from 20-85\%; the higher concentrations ( $\mathrm{S} / 2$ and $\mathrm{S} / 4$ ) were more effective than lower concentrations (S/8 \& S/16). Maximum larval mortality (84.7 \%) was recorded in RKB-91 strain of Bacillus sp. at $\mathrm{S} / 2$ concentration, which exhibited $68 \%$ mortality even at the S/4 concentration followed by Bacillus sp. RKB65. The lowest mortality $(05.00 \%)$ was observed in water (control). All the five rhizobacterial strain were effective in nematode mortality $(62.9 \%)$ at $\mathrm{S} / 2$ 
concentration. As the concentration of rhizobacterial cultures decreases the larval mortality decreased. Among all the five rhizobacterial strains maximum mortality $(57.7 \%)$ was observed in one of Bacillus sp. RKB-91 irrespective of their concentrations. The interaction between the rhizobacterial cultures and their concentrations were found significant in larval mortality.

\section{Mortality test by cell free culture filtrates}

It is evident from (Table 2) that the rhizobacterial Cell Free Culture filtrates (CFs) were successful in larval mortality of $M$. graminicola. All the bacterial CFs resulted in nematode mortality ranging from $20-81 \%$. Maximum larval mortality $(81.0 \%)$ was recorded in RKB-91 strain of Bacillus sp. at $\mathrm{S} / 2$ concentration. This strain exhibited about $67.7 \%$ mortality even at the $\mathrm{S} / 4$ concentration followed by Bacillus sp. RKB-65. The lowest mortality $(5.4 \%)$ was observed in water (control). All the five bacterial strain were effective in nematode mortality $(59.3 \%)$ at S/2 concentration and least mortality $(21.3 \%)$ was observed in $\mathrm{S} / 16$ concentration irrespective of rhizobacterial strains. Among all the five rhizobacterial strains maximum mortality $(54.8 \%)$ was observed in one of Bacillus sp. RKB-91 irrespective of their concentrations. The interaction between the $\mathrm{CFs}$ and their concentrations were found significant in larval mortality. This is understandable because several metabolites of microbial origin have been reported to possess antibiosis effects against nematode activities.

Similar alleviating impact on antinemic activity of cell-free culture supernatants of 22 strains belonging to five species of rhizobacteria against $M$. graminicola egg hatching and juvenile motility. However, Gluconacetobacter diazotrophicus Co99-70, Pseudomonas spp. RKP-33, Bacillus spp. RKB-91 and RKB-68 significantly delayed and decreased nematode egg-hatch and also irreversibly inactivated mobility of $64-77 \%$ of the treated juveniles within $24 \mathrm{~h}$ of exposure. Several metabolites of microbial origin have been reported to possess antibiosis effects against nematode activities. For example, volatile fatty acids produced by $G$. diazotrophicus are known to affect nematodes (Bansal et al., 2005). Similar type of results were found by Pankaj et al., (2011) to investigate the bacterial strains produced water soluble compounds that adversely affected the mobility of juveniles and egghatch. Seenivasan et al., (2012) evaluated the plant growth promoting rhizobacterium, Pseudomonas fluorescens strains PF1, TDK1, and PY15 were individually and in combinations for their efficacy against rootknot nematode, Meloidogyne graminicola, in rice plants under in vitro conditions. Culture filtrates of these strains either individually or as mixture inhibited egg hatching and caused mortality of juveniles of $M$. graminicola under in vitro. The efficacy was more pronounced when filtrates of the strain were used as mixtures than as individual strains. Similar type of results was found by Zaghloul, (2015) evaluated 19 rhizospheric bacterial isolates against Meloidogyne incognita. The five bacterial isolates (B38, B39, B78, B91 and B103) were the most effective bacteria against the resulting in (>94\%). Results also indicated that isolate B38 showed the highest mortality percentage of nematicidal volatile activity by $70.3 \%$. Bacterial cells suspension showed higher mortality than their cultural filtrates. The highest mortality percentages were recorded at dilutions $10^{-1}$ by all bacterial strains. This is understandable because several metabolites of microbial origin have been reported to possess antibiosis effects against nematode activities. Volatile fatty acids produced by $G$. diazotrophicus (Bansal et al., 2005) are known to disrupt and paralyse the movement of nematode (Djian et al., 1991). 
Table.1 Effect of cultures of rhizobacterial strains on larval mortality of M. graminicola

\begin{tabular}{|l|c|c|c|c|c|c|c|}
\hline \multirow{2}{*}{ Dilutions } & \multicolumn{7}{|c|}{ Rhizo-bacterial strains } \\
\cline { 2 - 8 } & AVK-51 & RKB-65 & RKB-91 & $\mathbf{3 5 - 4 7}$ & HT-54 & $\begin{array}{c}\text { Water } \\
\text { alone }\end{array}$ & Means \\
\hline S/2 & 71.67 & 80.00 & 84.67 & 62.67 & 73.33 & 5.00 & 62.89 \\
\hline S/4 & 51.67 & 61.33 & 68.33 & 50.33 & 53.33 & 5.33 & 50.06 \\
\hline S/8 & 33.33 & 40.33 & 44.33 & 29.67 & 39.33 & 5.67 & 32.11 \\
\hline S/16 & 24.33 & 36.00 & 33.33 & 22.67 & 30.33 & 5.67 & 25.39 \\
\hline Means & $\mathbf{4 6 . 0 0}$ & $\mathbf{5 4 . 4 2}$ & $\mathbf{5 7 . 6 7}$ & $\mathbf{4 1 . 3 3}$ & $\mathbf{4 9 . 8 3}$ & $\mathbf{5 . 4 2}$ & \\
\hline
\end{tabular}

C.D. at $5 \%$ level Bacterial strains: 2.36; Dilutions: 1.93; Bacterial strains x Dilutions: 4.72

Table.2 Effect of cell free culture filtrates (CF) of rhizobacterial strains on larval mortality of M. graminicola

\begin{tabular}{|l|c|c|c|c|c|c|c|}
\hline \multirow{2}{*}{ Dilutions } & \multicolumn{7}{|c|}{ Rhizo-bacterial strains } \\
\cline { 2 - 8 } & AVK-51 & RKB-65 & RKB-91 & $\mathbf{3 5 - 4 7}$ & HT-54 & $\begin{array}{c}\text { Water } \\
\text { alone }\end{array}$ & Means \\
\hline S/2 & 65.67 & 76.33 & 81.00 & 56.67 & 71.33 & 5.00 & $\mathbf{5 9 . 3 3}$ \\
\hline S/4 & 48.67 & 58.00 & 67.67 & 49.33 & 51.67 & 5.33 & $\mathbf{4 6 . 7 8}$ \\
\hline S/8 & 32.33 & 33.33 & 40.33 & 26.33 & 39.67 & 5.67 & $\mathbf{2 9 . 6 1}$ \\
\hline S/16 & 22.33 & 25.00 & 30.00 & 20.00 & 25.00 & 5.67 & $\mathbf{2 1 . 3 3}$ \\
\hline Means & $\mathbf{4 2 . 2 5}$ & $\mathbf{4 8 . 1 7}$ & $\mathbf{5 4 . 7 5}$ & $\mathbf{3 8 . 0 8}$ & $\mathbf{4 6 . 9 2}$ & $\mathbf{5 . 4 2}$ & \\
\hline
\end{tabular}

C.D. at $5 \%$ level Bacterial strains: 2.56; Dilutions: 2.09; Bacterial strains x Dilutions: 5.13

Table.3 Effect of cultures of rhizobacterial strains on egg hatching of M. graminicola

\begin{tabular}{|c|c|c|c|c|c|c|c|}
\hline \multirow[t]{2}{*}{ Dilutions } & \multicolumn{7}{|c|}{ Rhizo-bacterial strains } \\
\hline & AVK-51 & RKB-65 & RKB-91 & $35-47$ & HT-54 & $\begin{array}{l}\text { Water } \\
\text { alone }\end{array}$ & Means \\
\hline $\mathrm{S} / 2$ & 30.33 & 36.33 & 28.00 & 39.67 & 38.67 & 96.33 & 44.89 \\
\hline S/4 & 38.33 & 53.00 & 38.00 & 55.67 & 54.67 & 95.67 & 55.89 \\
\hline $\mathrm{S} / \mathbf{8}$ & 54.33 & 73.33 & 55.00 & 77.33 & 74.67 & 96.33 & 71.83 \\
\hline $\mathrm{S} / 16$ & 66.00 & 77.67 & 65.00 & 82.00 & 78.33 & 95.00 & 77.33 \\
\hline Means & 47.25 & 60.08 & 46.50 & 63.67 & 61.58 & 95.83 & \\
\hline
\end{tabular}

C.D. at $5 \%$ level Bacterial strains: 1.61; Dilutions: 1.31; Bacterial strains x Dilutions: 3.21

Table.4 Effect of cell free culture filtrates (CF) of rhizobacterial strains on egg hatching of $M$. graminicola

\begin{tabular}{|c|c|c|c|c|c|c|c|}
\hline \multirow[t]{2}{*}{ Dilutions } & \multicolumn{7}{|c|}{ Rhizo-bacterial strains } \\
\hline & AVK-51 & RKB-65 & RKB-91 & $35-47$ & HT-54 & $\begin{array}{l}\text { Water } \\
\text { alone }\end{array}$ & Means \\
\hline $\mathrm{S} / 2$ & 36.33 & 41.00 & 31.00 & 41.67 & 41.67 & 96.33 & 48.00 \\
\hline$S / 4$ & 46.33 & 56.33 & 40.67 & 58.33 & 56.00 & 95.67 & 58.89 \\
\hline $\mathrm{S} / \mathbf{8}$ & 64.67 & 76.67 & 57.33 & 78.67 & 79.00 & 96.33 & 75.44 \\
\hline$S / 16$ & 73.33 & 80.33 & 68.33 & 84.00 & 80.33 & 95.00 & 80.22 \\
\hline Means & 55.17 & 63.58 & 49.33 & 65.67 & 64.25 & 95.83 & \\
\hline
\end{tabular}

C.D. at $5 \%$ level Bacterial strains: 1.58; Dilutions: 1.29; Bacterial strains x Dilutions: 3.15 
Hatching test by rhizobacterial cell cultures

All rhizobacterial cultures showed inhibitory effect on egg hatching. The rate of hatching was inversely proportional to concentration of strains with 10 days of exposure period, as it decreased with increase in concentration. The minimum hatching of eggs $(44.9 \%)$ was observed in S/2 while highest rate $(77.3 \%)$ at S/16 concentration in all cultures tested (Table 3). Among all rhizobacterial strains Bacillus sp. RKB-91 showed most inhibitory effect $(46.5 \%)$ followed by Azotobacter sp. AVK-51 (47.3\%) in cultures. Minimum hatching $(<50 \%)$ was recorded with all rhizobacterial strains cultures after 10 days at $\mathrm{S} / 2$ concentration. The maximum egg hatching was recorded in water $(95 \%)$. The interaction between the rhizobacterial cultures and their concentrations were found significant in inhibiting egg hatching.

\section{Hatching test by cell free culture filtrates}

All Cell Free Culture filtrates (CFs) showed inhibitory effect on egg hatching. The rate of hatching was inversely proportional to concentration of CFs with 10 days of exposure period, as it decreased with increased in concentration. The maximum hatching of eggs $(80.2 \%)$ was observed in S/16 while lowest rate $(48.0 \%)$ of hatching at $\mathrm{S} / 2$ concentration in all cultures tested (Table 4). Among all bacterial strains Bacillus sp. RKB-91 showed most inhibitory effect (49.3\%) followed by Azotobacter chroococcum sp. AVK-51 (55.2\%) in CFs. Minimum inhibitory of hatching ( $>50 \%)$ was recorded with all rhizobacterial strains CFs after 10 days at $\mathrm{S} / 2$ concentration. The maximum egg hatching was recorded in water $(95 \%)$. Among all five rhizobacterial strains the Bacillus sp. RKB-91 exhibited highest inhibitory effect $(31.0 \%)$ followed by Azotobacter chroococcum sp. AVK-51
(36.3\%) at $\mathrm{S} / 2$ concentration. Thus the interaction between the $\mathrm{CFs}$ and their concentrations were found significant in egg hatching.

Similar type of results were found by Seenivasan et al., (2012) evaluated the plant growth promoting rhizobacterium, Pseudomonas fluorescens strains PF1, TDK1, and PY15 were individually and in combinations for their efficacy against rootknot nematode, Meloidogyne graminicola, in rice plants under in vitro conditions. Culture filtrates of these strains either individually or as mixture inhibited egg hatching of $M$. graminicola under in vitro. These results are in agreement with the present findings that Bacillus strain affected the egg hatching rate of $M$. graminicola. Rhizobacteria can have different modes of action on nematode populations. These include interfering with plant-nematode recognition, competing for essential nutrients, promoting plant growth, inducing systemic resistance or, probably the most important, directly antagonizing the nematode by producing toxins, enzymes and other metabolic by-products (Mendoza et al., 2008; Tian et al., 2007). However, detailed studies on the metabolic secretions of these bacterial isolates and their nematoxic attributes are warranted.

\section{References}

Bansal, R. K. and Bajaj, A. 2003. Effect of volatile fatty acids on embryogenesis and hatching of Meloidogyne incognita eggs. Nematologia mediterranea, 31, 135-140.

Bansal, R. K., Dahiya, R. S., Narula, N. and Jain, R. K. 2005. Management of Meloidogyne incognita in cotton, using strains of the bacterium

Gluconacetobacter diazotrophicus. Nematologia mediterranea, 33, 101-105.

Djian, C., Pijarowski, L., Ponchet, M., Arpin, N. and Favre Bonvin. J. 1991. Acetic acid: a selective nematicidal metabolite from culture filtrates of Paecilomyces lilacinus 
(Thorn) Samson and Trichoderma longibrachiatum Rifai. Nematologica 37: 101-112.

Dobbelaere, S., Vanderleyden, J. and Okon, Y. 2003. Plant growth promoting effects of diazotrophs in the rhizosphere. Critical Review in Plant Science, 22,107-49.

Gaur, H.S. 2003. Root-knot disease of rice and wheat: Problem and Management. Division of Nematology, IARI, New Delhi. pp. 23.

Gerber K, Smart G C Jr, Esser R P 1987. A comprehensive catalogue of plant parasitic nematodes associated with aquatic and wetland plants. Technical Bulletin 871 . Agricultural Experiment Station, Institute of Food and Agricultural Sciences, University of Florida, Gainesville, Florida.

Hussey, R. S. and Barker, K. R. 1973. A comparison of methods of collecting inocula of Meloidogyne spp., including a new technique. Plant Disease Reporter, 57, 1025-1028.

Padgham J. L. and Sikora R. A. 2007. Biological control potential and modes of action of Bacillus megaterium against Meloidogyne graminicola on rice. Crop Protection, 26, 971-977.

Padgham J.L., 2003. Impact of the rice root-knot nematode (Meloidogyne graminicola) on lowland rainfed rice production in northwestern Bangladesh. PhD dissertation. Cornell University, Ithaca, NY.

Padgham J.L., Abawi G.S., Duxbury J.M. and Mazid M.A., 2004a. Impact of wheat on Meloidogyne graminicola populations in the rice-wheat system of Bangladesh. Nematropica, 34: 183-190.

Padgham J.L., Duxbury J.M., Mazid A.M. Abawi G.S. and Hossain M., 2004b. Yield loss caused by Meloidogyne graminicola on lowland rainfed rice in Bangladesh. Journal of Nematology, 36: 42-48.

Pankaj, K., Bansal, R. K. and Nandal, S. N. 2010. Biocontrol of Meloidogyne graminicola using rhizobacteria on rice seedlings. Nematologia mediterranea, 38, 115-119.

Prasad, J. S., Panwar, M. S. and Rao, Y. S. 1985. Occurrence of root knot-nematode, Meloidogyne graminicola in semi-deep water rice. Current Science, 54, 387-388.

Roy, A.K. 1973. Reaction of some rice cultivars tothe attack of Meloidogyne graminicola. Indian J. Nematol., 3 72-73.

Seenivasan, N., David, P. M. M., Vivekanandan, P. and Samiyappan, R. 2012. Biological control of rice root-knot nematode, Meloidogyne graminicola through mixture of Pseudomonas fluorescens strains. Biocontrol Science and Technology, 22, 611-632.

Soriano I. R. and Reversat G 2003. Management of Meloidogyne graminicola and yield of upland rice in South-Luzon, Philippines. Nematology, 5: 879-884.

Soriano IRS, Prot JC, Matias, DM 2000. Expression of tolerance for Meloidogyne graminicola in rice cultivars as affected by soil type and flooding. J. Nematol., 32: 309317.

Tian, B., Yang, J. and Zhang, K.Q. 2007. Bacteria used in the biological control of plantparasitic nematodes: populations, mechanisms of action and future prospects. FEMS Microbiology and Ecology, 61, 197213.

Zaghloul, R. A., Neweigy, N. A., Aboualy, H. E., El-Sayed, S. A. and Bahloul, A. M. 2015. Nematicidal Activity of Some Biocontrol Agents against Root-Knot Nematodes InVitro. Research Journal of Pharmaceutical, Biological and Chemical Sciences, 6, 429438.

\section{How to cite this article:}

Matcha Udaya Kumar, R.K. Walia and Kanwar, R.S. 2018. In vitro Effect of Rhizobacterial Strains against Rice Root Knot Nematode Meloidogyne graminicola. Int.J.Curr.Microbiol.App.Sci. 7(12): 2772-2778. doi: https://doi.org/10.20546/ijcmas.2018.712.314 